\title{
Application designed for the elderly using gestural interface
}

\author{
André Luiz Satoshi Kawamoto ${ }^{1}$ \\ Valéria Farinazzo Martins ${ }^{2}$
}

\begin{abstract}
Resumo: Atualmente, o envelhecimento da população tem atraído o interesse de diferentes áreas de pesquisa, tais como Saúde, Ciências Sociais e Economia. O envelhecimento pode provocar fenômenos indesejáveis associados à fraqueza muscular, perda de memória e perda de autonomia. Este trabalho apresenta uma aplicação de computador baseado no Teste de Corsi projetado para o público idoso. O aplicativo pode ser usado para testes e treinamento de memórias visuoespaciais. O desenvolvimento de aplicações é apresentado, e sua avaliação de usabilidade é detalhada. A principal contribuição deste trabalho é a reinterpretação e a compilação das diretrizes para jogos sérios para pessoas idosas.
\end{abstract}

Palavras-chave: Interfaces gestuais. Avaliação e teste de usabilidade. Jogos sérios. Kinect.

\begin{abstract}
Nowadays, population aging has attracted the interest of research areas such as Health, Social Sciences, and Economics. Aging can trigger unwanted phenomena associated to muscle weakness, loss of memory and loss of autonomy. This paper presents a computer application based on the Corsi Test designed for the elderly audience. The application can be used for testing and training visuo-spatial memory. The application development is presented, and its usability evaluation is detailed. The main contribution of this work is the reinterpretation and compilation of guidelines for serious games for older adults.
\end{abstract}

Keywords: Gesture-based interface. Usability evaluation and usability test. Serious games. Kinect.

\section{$1 \quad$ Introduction}

According to the IBGE (Instituto Brasileiro de Geografia e Estatítistica - Brazilian Institute of Geography and Statistics) [18], by the year of 2050, one fifth of the Brazil population will be formed by people over sixty years-old. This increase in the elderly population is due to factors related to medical and technological advances; basic sanitation improvements; prevention, control and cure of diseases which were considered fatal; reduction of the mortality rate and the augment of the life expectancy, even in developing countries.

Despite the clear advantages associated to seniority, aging can also have negative physical, cognitive, and social consequences. Average visual and auditory acuity decline considerably with age as well as the average strength and the speed of response. Some people may experience loss of at least some kinds of memory function, declines in perceptual exibility, slowing of "stimulus encoding" and increased difficulty in the acquisition of complex mental skills [43].

Facing this scenario, several areas, including Medicine, Occupational Therapy, Physiotherapy and Nutrition have addressed the physiological changes caused by the aging process, mainly the neuropsychological changes engaged in cognitive processes, such as learning and memory [45]. Loosing or reducing these functions

\footnotetext{
${ }^{1}$ Universidade Tecnológica Federal do Paraná, via Rosalina Maria dos Santos, 1233 CEP 87301-899 Caixa Postal: 271 Campo Mourão - PR - Brasil

$\{$ kawamoto@utfpr.edu.br\}

${ }^{2}$ Faculdade de Computação e Informática Universidade Presbiteriana Mackenzie, Rua da Consolação, 930 - São Paulo - SP Brasil

\{valeria.farinazzo@mackenzie.br\}
}

http://dx.doi.org/10.5335/rbca. 2013.3269

Revista Brasileira de Computação Aplicada (ISSN 2176-6649), Passo Fundo, v. 5, n. 2, p. 96-109, out. 201396 
may compromise the welfare of the elderly, preventing them from the continuity of an active social life, with family and social interactions.

Previous studies have reported that, in a healthy aging process, it is possible to compensate (at least partially) cognitive deficits $[4,5,11]$. Research on cognitive and memory training shows that a healthy older citizens are able to perform tasks very close to the best possible, revealing cognitive plasticity [46]. In fact, stimulating the memory in the elderly improves considerably the cognitive aspect [3, 20, 49].

Besides, research has shown that playing games can have positive effects on the emotional and physical well-being of elderly people, and can motivate them to maintain a basic level of physical and memory activity $[7,22]$.

Using non-conventional devices, such as the Microsoft Kinect [31], may offer a good opportunity to create games able to motivate the physical and memory features of the elderly. However, the games can provide real danger to these people [14]. Thus, it is necessary to take into consideration usability criteria, such as exertion management, age-inclusive design and simple setup routines [15].

This work presents the development of a digital memory application based on Microsoft Kinect that reproduces the Corsi Test [27], and the results of an Usability Evaluation performed to determine usability issues. The paper is organized as follows: in Section 2 types of memory and aging effects are showed; Section 3 introduces a small survey on projects aiming the elderly audience, as well as projects that uses the Microsoft Kinect as interface device; in Section 4 the guidelines addressed to age-related disabilities are presented; in Section 5 the requirements and technology used in the implementation of the application are detailed; in Section 6 the Methodology used to perform the evaluation is presented, and in Section 7 evaluation results are presented. Section 8 presents the Final Considerations and Future Work.

\section{Types of Memory and Aging Effects}

Shneiderman [3] describes three types of memory, as well as the process of information input and retrieval: Short-Term Memory; Temporary Memory and Long-Term Memory.

Short-Term Memory receives input information captured by the sight, hearing, smell, taste and touch and passes it to the cognitive system. This type of memory is also where the output information is placed, that is, information expressed by speaking, gesture and actions. Storing in this memory takes about 10 seconds, and its capacity is quite limited. According to Miller [32], the total amount of information is $7 \pm 2$. In other words, when capturing a certain number of information, Short-Term Memory is able to hold an average of 7 information, with average variation of 2 , i.e. between 5 and 9 information.

Temporary Memory (or Working Memory) is where the information that comes from the Short-Term Memory is handled and concatenated, before sending to Long-Term Memory. Thus, the information is kept for longer periods of time than Short-Term Memory, but not in a permanent way.

Finally, Long-Term Memory is able to store a large amount of information for long periods of time. For instance, facts that occurred a long time ago and that a person is able describe in detail.

The access to information is not limited to Working Memory. Short-Term Memory can, exceptionally, act as a way of access. The information that takes this "shortcut" does not require any retrieval mechanism - for instance names, addresses, and phone numbers. These information is learned by people learn very early in life and can be recalled automatically. However, when the phone number or the car license plate number is changed, it will be necessary, in the beginning, to be associated to some retrieval mechanism of Working Memory in order be retrieved.

According to Souza and Chavez [45], a substantial portion of the elderly population complains on the difficulty of storing and retrieving information, for instance for taking medicine, locating objects, and naming known people. In cognitive aspects, older adults often experience cognitive impairments, which affect problem solving skills, information processing and result in a reduced attention span when working on complex tasks [22].

In order to investigate how to reduce the memory loss in the elderly by means of stimuli, several studies in the Medicine area have been carried out [6,9]. In its turn, studies in Human-Computer Interaction area aim to 
establish guidelines for building interfaces able to adapt themselves to the human memory characteristics, which do not require over the necessary and feasible memory skills.

In Games Development area, it is possible to couple these interests, that is, to build games and interfaces adaptable to the memory characteristics and that can inhibit memory loss in the elderly, in a playful way. Computer games are also attractive for older adults, because they stimulate social interaction, provide practice in sensori-motor skills such as eye-hand coordination, enhance dexterity, and improve reaction time.

\section{Related Work}

Several works have studied the development of applications to stimulate and enhance the elderly wellbeing. Besides, there are another set of works that investigate how to push the Microsoft Kinect to areas further than its original purpose, like 3D modeling, education, surveillance and monitoring people.

This section introduces a short survey on applications to the elderly audience and their intrinsic characteristics, as well as the use of the Microsoft Kinect in the development of applications.

First, in [28], serious games for the older citizens are classified according to their specific goal and key design elements for improving the physical health of the target audience. This work shows that projects tend to take into consideration elder user needs in gaming design for health purposes, but little effort has been made to take into account the limitations of the aged group of users along the entire design process. It also points out that testing phases and usability evaluation are needed, and finally, it claims that the use of modern input devices has allowed specialists to determine the patient performance in terms of motor functions. Nevertheless, the potential of use this capability to accurately perform medical assessment as a tool to guarantee effectiveness is not yet being totally exploited.

In [16], the challenges and opportunities of a new approach in motion-based game design for older adults are discussed. The importance of identifying challenges and involves both users and experts in the design process can help game developers create safe, accessible and enjoyable motion-based games for older adults. As a conclusion, the authors argue that this approach could also contribute to the development of games for other user groups that consist of members with heterogeneous abilities and needs, fostering the creation of enjoyable games for vulnerable audiences.

The limitations of current design philosophies and opportunities to facilitate the creation of accessible motion-controlled video games are highlighted in [15]. The work presents seven guidelines for the design of fullbody interaction in games for older adults. The guidelines are designed to foster safe physical activity among older adults, thereby increasing their quality of life. Some of the challenges to increase the quality of games and to improve game design processes, along with possible approaches, aiming to fuel intensified exchange about methodological experiences among researchers in the field are reported and classified in [44]. The authors suggest that, in order to obtain reliable results when evaluating exergames, it is necessary to provide methods which reduce the cognitive load of participants instead of overwhelming them by presenting too many new challenges at the same time. Small adjustments to the evaluation environment, accomplished with providing simple, specifically designed questionnaires, reading them out as structured interviews and keeping the session duration as short as possible helped reduce the cognitive load of participants experiencing age-related changes. It is also said that it is crucial to gain insights into long-term effects and detailed physical effects, which requires research methods that go far beyond those designed to examine exergames usability and accessibility.

In [12], an overview of common age-related changes, followed by a summary of game design considerations for senior audiences are presented. The impact of age on game design is based on an analysis of the most important structural elements of games. The analysis shows that age-related changes in the cognitive and physical user abilities affect the use of games on multiple levels, making the complexity of games and interrelations between different game mechanics a crucial factor when designing for older adults.

Kinect has been used as a low cost device in the development of applications for monitoring, virtual rehabilitation, 3D Modeling, serious games [8, 23, 24, 26, 29, 37, 40]. However, most of these works is focused on the technical aspects of adopting this technology, like accuracy, adequate illumination and positioning. Its usability is based on the assumption that the Natural User Interface provided by Kinect has a better approach to users.

Revista Brasileira de Computação Aplicada (ISSN 2176-6649), Passo Fundo, v. 5, n. 2, p. 96-109, out. 201398 
Our work proposes a Usability Evaluation of a Microsoft Kinect based interface, in the context of elder population. The evaluation of gesture interfaces for older adults is quite novel. Our evaluation addresses questions like muscular fatigue, ease of learning to use, expectations on the application and level of motivation related to the use of the device.

\section{Guidelines Addressed to Age-Related Disabilities}

During the lifetime, the human body and the human mind are continuously subject to changes in practically all aspects of perceptual, cognitive, and motor functioning. This section presents some possible reasons why seniors do not use or dislike using computer devices.

According to [34], 45\% of older adults showed behaviors that indicated they were uncomfortable trying new things or hesitant to explore new technologies. In [16], some suggestions are stated to stimulate elders to engage and play:

- $\quad$ game must be playful, in other words, people should enjoy spending the time playing it;

- game must involve another gamers, if possible. The reason is that playing with others tend to be more attractive than playing alone; this also explains the next guideline, which is the players shall be encouraged to use collaboration and competition;

- games shall be developed according to the gender of the players, because men and women may have different themes topics of interest.

The major concern of the research projects found in the literature is related to cognition issues. According to [10], there are two developmental trends on the cognitive level, namely "crystallized intelligence" and "fluid intelligence", related to types of task and function.

Crystallized intelligence is supposedly associated to the acquisition of new knowledge, improvement of skills, and extending the vocabulary. Even at a high age people are quite able to use this store of knowledge, and may score higher than younger people on tasks requiring vast stores of information and establishing relations between pieces of information. On the other hand, fluid intelligence is used in tasks where speed of processing is necessary. Although younger people are both faster and more accurate than older ones, when given more processing time, older people can attain the same level of accuracy. Thus, the speed of processing seems to be the crucial difference between older and younger persons, which give credibility to the idea that the perceptual world is also typified by its own temporal course of events.

Still according to [10], the loss of memory in older adults is essentially related to the same timing problem. While primary memory is hardly affected in old age, it involves retaining a few items with minimal processing. As more the number of items to be remembered increases, the memory performance decreases rapidly.

Apparently, the more encoding time is available the, more the memory performance improves. It seems that older people tend to spend a longer time on encoding, but estimate that this period of time is sufficient for successful recall, which actually it is not. Yet, the encoding time taken corresponds to the time they took in earlier phases of life, which has largely become automated and is hard to change.

Several works present how the memory decline can be mitigated by stimulation through games provide a list of guidelines:

- $\quad$ games must avoid the use of prior information, such as RPG games [16, 32, 41];

- $\quad$ games must use simple interactions $[2,19,33]$;

- quick and complex interactions $[16,19,41]$ as well as quick and parallel actions must be avoided;

- learning time should be greater [16];

- $\quad$ games should embed familiar metaphors [16, 41];

- $\quad$ during the period of the game, additional and more detailed information should be provided [16];

- $\quad$ complex screen must be avoided [2, 19, 34, 36, 41];

- $\quad$ redundant information through multiple modalities should be provided [10, 19, 34, 41];

- $\quad$ load on memory and cognitive processing should be kept to a minimum $[19,41]$;

- avoid contradictions and inconsistencies of information arrangement [41], because they may confuse the users; 
- in gestural interfaces, it is advisable to use a set of few and easy movements [13].

Another issue related to aging is the decline of senses, which become less sharp. Every information received from the environment, in the form of sounds, lights, smells, tastes, and touch is converted to nerve signals and carried to the brain, where it is turned into a meaningful sensation. In games, vision and audition are the most stimulated senses.

According to [41], issues related to the vision loss of seniors start to become more obvious around 60 years old. The visual field reduce, which makes it become more suitable to adjust the focusing point of the information devices to be stronger and closer to the center of the visual field.

Older people have less sensitivity to color contrast than the younger people, especially in the blue-green range. Additionally, seniors have the capability decreased in tone detection in different frequencies. Hearing is also affected, being difficult to them hearing high pitched sounds with peaks over $2500 \mathrm{~Hz}$ [41].

To preserve the sensations that games are designed to provide, it is suggested to:

- use appropriate size of objects and source text, as well as higher contrast [1, 2, 16, 19, 34, 41, 42];

- avoid synthetic speech, because it may be hard to be understood by older people [19,41];

- for non-speech audio signals, prefer lower frequency tones (in the 500-1000 Hz range), which are easier for elderly users to hear than higher pitched sounds $[10,19]$;

- avoid small targets and moving interface elements [19], and use appropriated colors [12];

- use appropriate illumination and try creating intuitiveness [19].

Aging is accompanied by impairments in motor skills. When people age, they perform complex tasks more slowly and, in some cases, less accurately. This physical decline is one of the general problems for the elders. Usually, seniors are slower in movement and response time, they consider harder to find a small target and are less accurate in their movements than younger people. That is, it can be implied that seniors may have difficulties to deal with general computer interactions, which are not designed for them [41].

In order to deal with it, literature review suggests the following guidelines:

- create slower response times [3,16, 19];

- avoid continuous and flexible movements [19];

- avoid a great variability in movement [19];

- take into account motor disabilities $[16,32,41]$;

- try including Health stuff $[19,48]$.

According to [10], all the sensory modalities perceptual acuity start to continuously diminish at the midtwenties age, and this process assumes a more progressive character after the sixty years-old, on average, but with a large variability, both in time of onset and in extent. This is valid for more complex functions like speech comprehension, demonstrating a developmental nature of the changes. Such slow and mostly imperceptible changes over such a long time unavoidably lead to a different perception of the environment, creating a "perceptual world" inherent to the person.

Addressing such declines in perception abilities, two suggestions are provided: using multimodal feedback for important information [2, 19 42]; and providing appropriate affordances [19], that is, visual hints to the function of objects.

Despite a larger number of older adults is becoming involved in usability studies, there is a lack of information on their motivation. It has been assumed that people become more patient as they get older. Conversely, older people seem to act more impatiently. The reason for this may be an increasing awareness of impending limitations, or even the proximity of death. Thus, they seem to prefer a small reward immediately than a larger one later, when it could become out of reach. Although frailty and health limitations could play an important role here, it appeared that the age effect was stronger than the health effect. Still it has to be kept in mind that health is strongly negatively correlated with age [10].

Dealing with this possible lack of motivation, in strategy games, it is suggested to provide positive feedback for initial users [19]; also, the interface should be adaptable [1, 10, 13, 37], allowing both initial and expert users to adjust it according to their specific needs.

Observation has shown that some guidelines addresses more than one specific disability, or are related to general issues. These guidelines, classified as "General Guidelines", state that:

Revista Brasileira de Computação Aplicada (ISSN 2176-6649), Passo Fundo, v. 5, n. 2, p. 96-109, out. 2013100 
- the interface should clearly express where the user is in the dialogue, and which "tasks" are active [2]. This addresses the declines in perception abilities, the changes in cognition, and even may be useful to avoid the lack of motivation for Initial and Expert Users;

- the structure of the task must be clear, with a starting point and steps easily recognized and understood [41];

- applications should continuously provide easily recognized feedbacks of success or failure of every action [41];

- output messages should be as short as possible [50];

- choices should be as few as possible, whereas confirmatory statements should be as much as possible [50].

To summarize, the group of guidelines specific for designing applications for older adults addresses all the disabilities related, and is intended to provide hints to system developers to build more suitable interfaces for this audience.

\section{Application Development}

Prior to the development of the application, a psychologist specialized in memory issues from the Neurosciences Laboratory was consulted. The professional uses a test to analyze the amount of information stored as part of the treatment for visuo-spatial memory, named Corsi Test.

The functioning of the test consists of a table presented to the patient. On top of it nine blocks are randomly placed. The conductor of the experiment touches the blocks, one after the other, in a sequence that must be repeated by the patient. The first sequence is composed by only one block, the second one takes two blocks, and so on, until the maximum number of nine blocks. Each sequence is different from the previous one. This is a short-memory term spatial memory test, where the subject of the experiment must keep in mind, for a short period of time, the positions of the blocks placed by the conductor. The average number is four or five blocks remembrance.

Some requirements were expressed during elicitation phase:

- the computer application must simulate the real test;

- since it can be executed without the presence of a professional, data should be recorded in a file for analysis;

- the application should run in two modes. The test mode provides no feedback should be provided to the user, whereas the training mode must allow the user to know if the informed sequence was correct

The professional also commented expectation on this game application, that is, since the Kinect device also stimulates physical (spatial) aspects of the patient, significant enhancements can be achieved when using it as a training tool. Among the technologies available to develop Kinect applications for hardware and software platforms different from the XBox 360 - OpenNI, OpenKinect, Microsoft SDK [31, 38, 39], the application uses the Microsoft Kinect SDK in its implementation, which is the Microsoft solution for creating applications for the Windows Operating System. The Microsoft SDK supports the CH, C++, and Visual Basic programming languages, and requires Windows 7 or superior. It enables to use several capabilities, for instance face tracking, voice commands, skeleton tracking, and others. The interface of the application is shown in Figure 1.

The whole set of guidelines was observed (section 4), and the developers adopted all the guidelines which were considered suitable for the applications. Thus, only a few guidelines were not followed, due to restrictions in the characteristics of the applications, or due to restrictions and requirements a professional introduced during the Requirement Engineering Phase. The following guidelines were not followed:

- the game must involve another gamers, if possible;

- the games shall be developed according to the gender of the players;

- avoid synthetic speech. 


\section{Evaluation Methodology}

A preliminary usability evaluation of the Kinect Corsi Test was carried out with 11 people from both genders, five men and six women aged between 18 and 63 years old. According to Nielsen [36], five users are enough to evaluate the usability of a system, especially when the goal is to find usability errors. Figure 2 shows the application in use. Albeit being originally designed for the elderly audience, the test aims to report enhancements and adjustments to the development team so that, in a second moment, repeat the usability evaluation along with the memory tests with the target group. Two users in the experiment were older than 60 years.

They were asked to attend an interview after the experiment to obtain more usability-related information. The experiment environment is not controlled. The tests took place in two different environments - a University room and, in some cases, the house of some users. Three questionnaires were conceived: profile, expectations and post-test.

The profile questions, based and adapted from [33], investigated the age, gender, computer games expertise, physical activities history and whether the user was familiar with the Microsoft Kinect or not. The expectations questionnaire, in its turn, used the five-point Likert scale [25], and investigated the level of interest of the user on the application, ease of use, level of motivation, and whether the user like to try new technologies or not. It was based and adapted from [17].

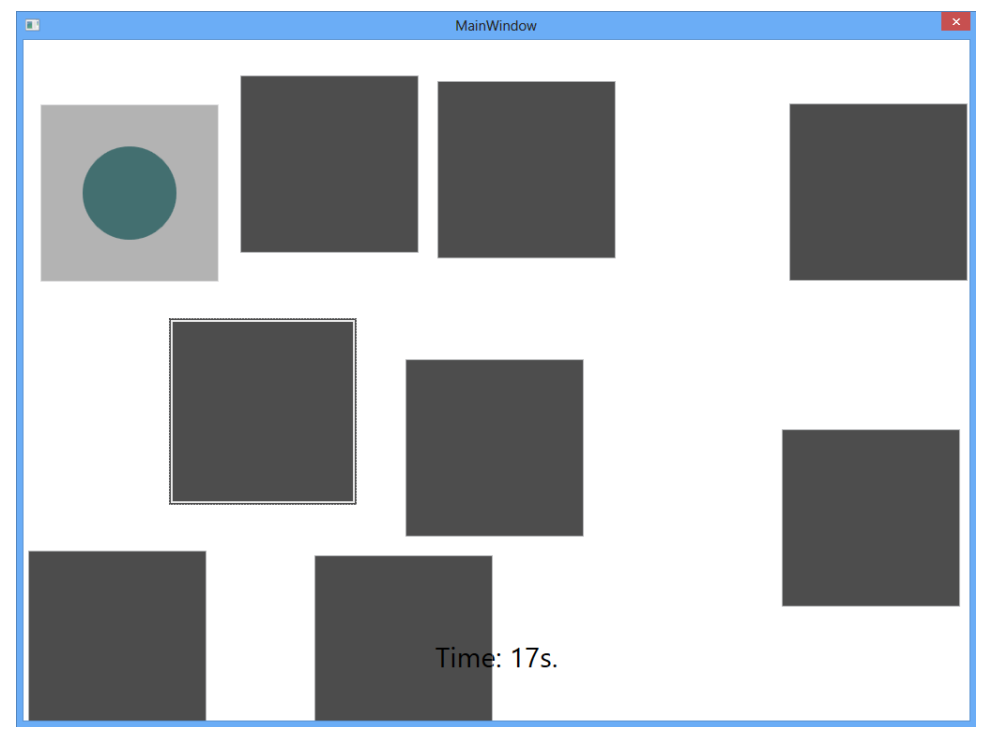

Figure 1: Application Interface

Finally, the post-test questionnaire also used the five-point Likert scale, and was adapted from [30] and from the Web Usability Questionnaire [47]. This set of 20 questions addressed Usability issues pointed out by Nielsen [35], like feedback, time of learning, and user satisfaction, effectiveness and efficiency indicated by ISO 9241-11 [21] and also the guidelines presented in Section 4. These questions are presented in Table 1. The test materials (camera, handouts, computer, Kinect device) were previously prepared, and a pilot-test was executed to avoid interferences and errors during the real experiment. The pilot-test showed that it would be necessary 25 minutes: 3 minutes to explanations, 3 minutes to the users answer the pre-test questionnaires (profile and expectations), 10 minutes to allow the novice users to try the Kinect for the first time and to adapt to its interaction mechanisms, 6 minutes for the test itself and more 3 minutes to answer the post-test usability questions. 


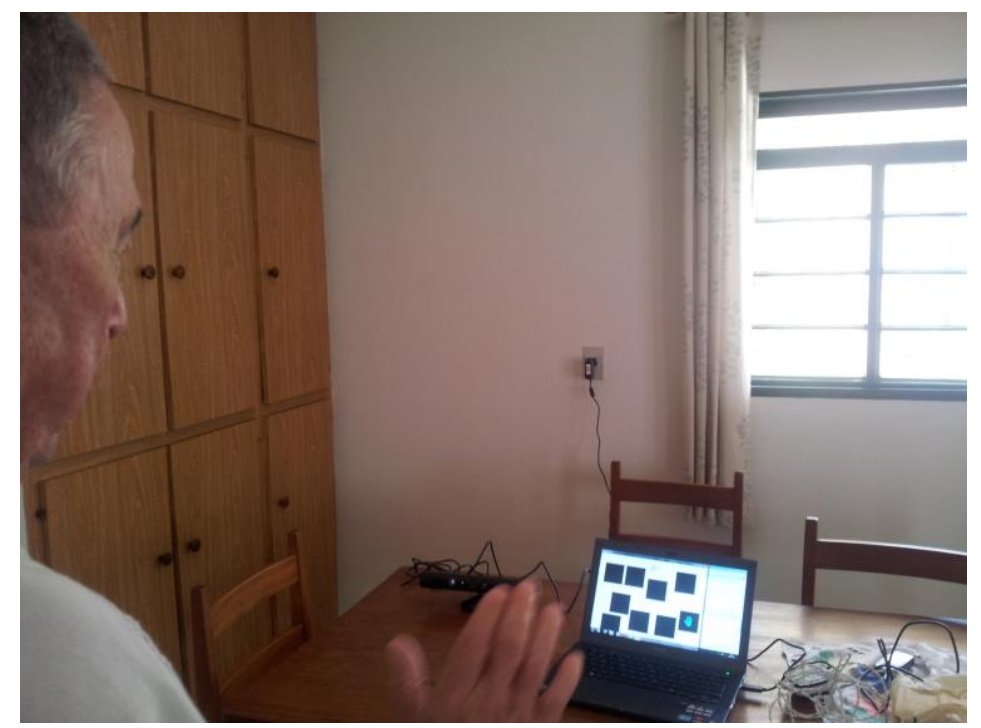

Figure 2: User interacting with the Application

\begin{tabular}{|c|c|}
\hline QUESTIONS & BASED ON \\
\hline $\begin{array}{l}\text { 1. Whenever I pointed the hand to the application, I } \\
\text { was able to "Click". }\end{array}$ & 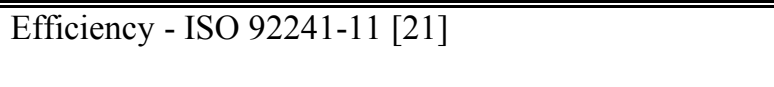 \\
\hline $\begin{array}{l}\text { 2. The application warned me when I comitted an } \\
\text { error. }\end{array}$ & Feedback - Nielsen [35] \\
\hline $\begin{array}{l}\text { 3. The application did not cause any muscular } \\
\text { fadigue. }\end{array}$ & $\begin{array}{l}\text { Avoid continuous and flexible movements [19]; } \\
\text { Avoid a great variability in movement }[19] ; \\
\text { Take into account motor disabilities }[16,19,41] ; \\
\text { In gestural interfaces, it is advisable to use a set of few } \\
\text { and easy movements [13]. }\end{array}$ \\
\hline 4. The application is quite enjoyable to use. & Satisfaction - ISO 92241-11 [21] \\
\hline $\begin{array}{l}\text { 5. The Kinect movements are more precise than } \\
\text { using a mouse. }\end{array}$ & Efficiency - ISO 92241-11 [21]. \\
\hline $\begin{array}{l}\text { 6. My movements are faster using the Kinect than } \\
\text { the mouse. }\end{array}$ & Efficiency - ISO 92241-11 [21]. \\
\hline 7. Kinect located me and my hand easily. & Efficiency - ISO 92241-11 [21]. \\
\hline 8. I feel efficient while I'm playing the application. & Efficiency - ISO 92241-11 [21]. \\
\hline $\begin{array}{l}\text { 9. I quickly understood how to interact with the } \\
\text { game. }\end{array}$ & $\begin{array}{l}\text { Load on memory and cognitive processing should be } \\
\text { kept to a minimum }[19,41] \text {. }\end{array}$ \\
\hline $\begin{array}{l}\text { 10. The application is very intuitive and easy to } \\
\text { understand. }\end{array}$ & $\begin{array}{l}\text { Load on memory and cognitive processing should be } \\
\text { kept to a minimum }[19,41] \text {. }\end{array}$ \\
\hline 11. I would definitely use the application again. & Satisfaction - ISO 92241-11 [21]. \\
\hline $\begin{array}{l}\text { 12. Even at the first time, it can be assumed that } \\
\text { this application is easy to use. }\end{array}$ & $\begin{array}{l}\text { Load on memory and cognitive processing should be } \\
\text { kept to a minimum }[19,41] \text {. }\end{array}$ \\
\hline $\begin{array}{l}\text { 13. I did not feel stressed by this game in any } \\
\text { situation. }\end{array}$ & Satisfaction - ISO 92241-11 [21]. \\
\hline $\begin{array}{l}\text { 14. It is quite easy to remember how to use this } \\
\text { application. }\end{array}$ & Load on memory and cognitive processing should be \\
\hline
\end{tabular}




\begin{tabular}{|c|c|}
\hline & kept to a minimum $[19,41]$. \\
\hline 15. My time was very spent using the application. & Satisfaction - ISO 92241-11 [21]. \\
\hline $\begin{array}{l}\text { 16.Everything in the application is easy to } \\
\text { understand. }\end{array}$ & $\begin{array}{l}\text { Load on memory and cognitive processing should be } \\
\text { kept to a minimum }[19,41] \text {. }\end{array}$ \\
\hline $\begin{array}{l}\text { 17. The size of the buttoms were suitable for } \\
\text { playing. They did not hindered. }\end{array}$ & $\begin{array}{l}\text { Avoid small targets and moving interface elements } \\
\text { [19] }\end{array}$ \\
\hline $\begin{array}{l}\text { 18. I believe I could play for a long time, even } \\
\text { standing. }\end{array}$ & $\begin{array}{l}\text { Avoid continuous and flexible movements [19]; } \\
\text { Avoid a great variability in movement [19]; } \\
\text { Take into account motor disabilities [16, 19, 41]; } \\
\text { In gestural interfaces, it is advisable to use a set of few } \\
\text { and easy movements [13]. }\end{array}$ \\
\hline $\begin{array}{l}\text { 19. The position I assume when I play is not } \\
\text { uncomfortable and does not force me to stop playing. }\end{array}$ & $\begin{array}{l}\text { Avoid continuous and flexible movements [19]; } \\
\text { Avoid a great variability in movement }[19] ; \\
\text { Take into account motor disabilities }[16,19,41] \text {; } \\
\text { In gestural interfaces, it is advisable to use a set of few } \\
\text { and easy movements [13]. }\end{array}$ \\
\hline $\begin{array}{l}\text { 20.The colors of the buttoms (blocks) are easily } \\
\text { identified when selected. }\end{array}$ & Use appropriated colors [12]. \\
\hline
\end{tabular}

Table 1: Questionnaire post-test

\section{Results}

The profile questionnaire results shows that five users were women and 6 were men; 6 users had never used the Kinect before. Regarding the use of computer games as entertainment, 6 of them never or rarely play computer games, whereas four users do it on a week basis, and one plays computer games monthly. Concerning physical activities, six people said that never performed.

Graphics depicted in the Figures 3 and 4 show the answer compilation results about the questionnaire post-test presented in Table 1.

Considering the data displayed in the graphics, it can be concluded:

- the game does not provides feedback to the users when they committed a mistake. Although this is a desirable feature, this version was designed to be used by the team of psychologists that analyses the short memory term capacity. The error rate data is written in a text file by the application;

- the users noticed that interacting with hands is not always as fast or as precise as the mouse but, due the fact it is an playful application, they were impelled to repeat the activity;

- the users considered the interface intuitive, easy to learn and to play even in the first time, and also easy to remember how to play;

- the users considered that playing for long periods of time would be bad, because they must be standing and using the arms and hands, in a position that was considered uncomfortable;

- imprecise movements, specially the novice users, they did not consider annoying to have to repeat the action until reach the correct movement.

The interview with the two users with more than 60 years old revealed that one person does exercise on a regular basis, whereas the other one does not. Both users had never used Kinect before, they are university employees and rarely use computer games. These users had a good expectation about the Usability Evaluation of 
an Application Designed for the Elderly application, but were not sure whether it would be easy to use or not. After the experiment, they said that the game was very motivational, they would certainly use it again and, after a few time to adapt, they would be able to use it with no problem. They also considered that the interaction was very intuitive and that they could become experts in a few time.

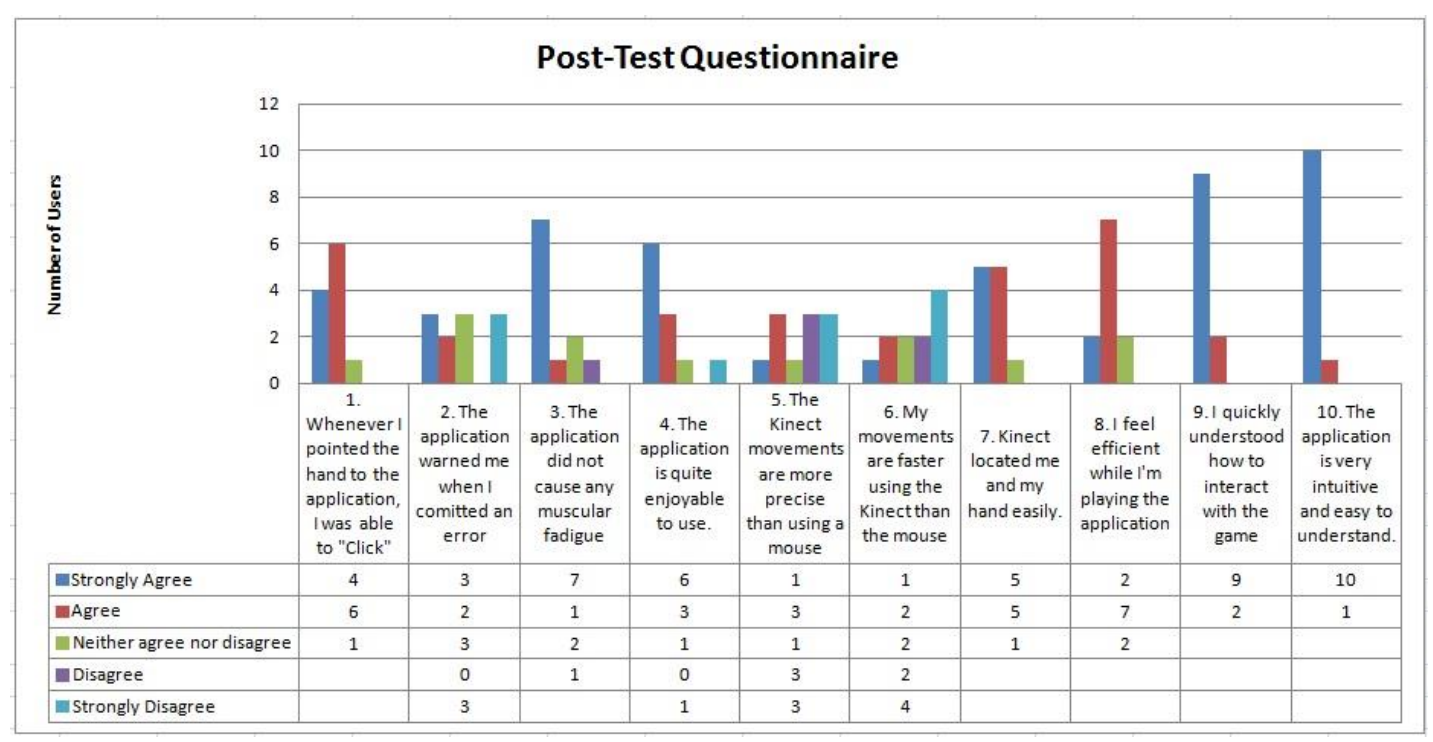

Figure 3: Evaluation Results - Post Test (1)

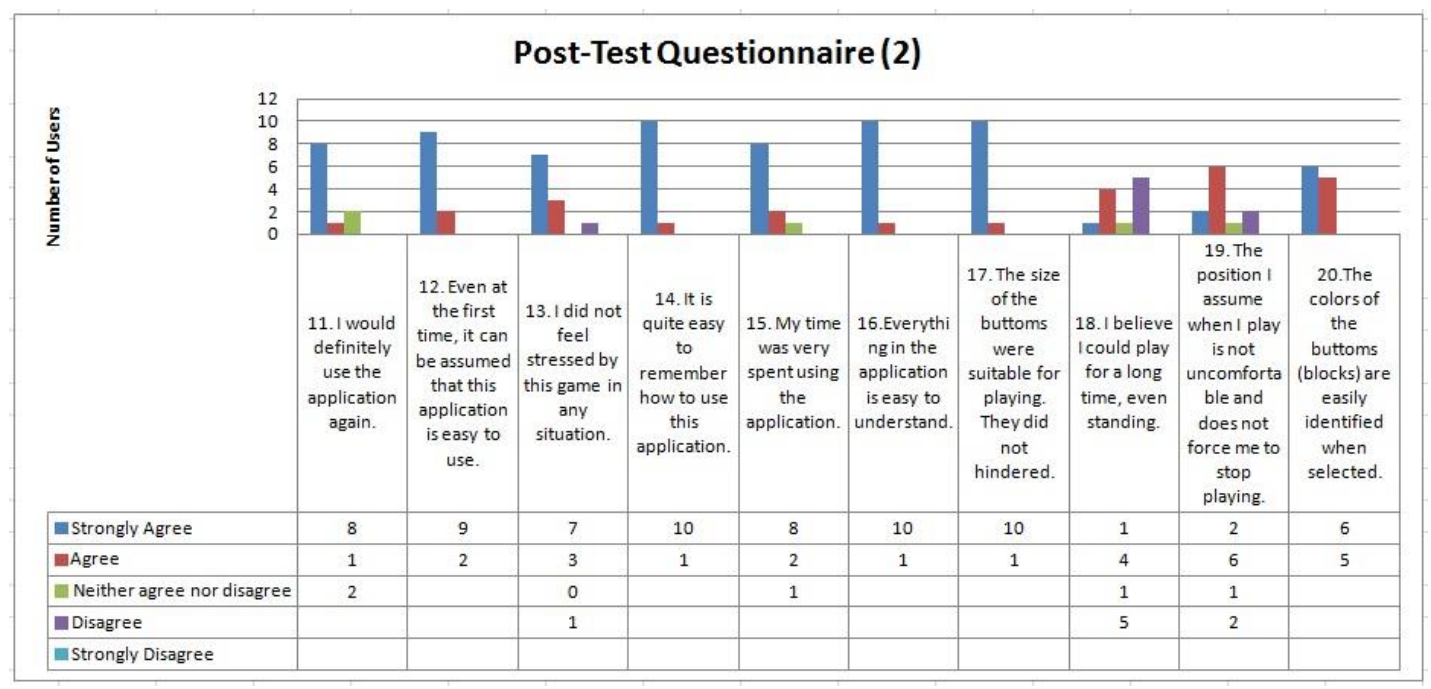

Figure 4: Evaluation Results - Post Test (2)

\section{Final Considerations and Future Works}

This paper presented the development of a Kinect application for the elderly. Its main contribution relies on the usability guidelines for applications for this particular target audience, and a usability evaluation process, which was quite detailed here. The development of applications for the elderly audience requires some design guidelines $[1,2,3,10,13,16,19,34,41,42,48,50]$ to kept in mind, in order to avoid discomfort or even risks to this population. It is also necessary to point out that building serious games requires a multidisciplinar team 
which includes skilled health professionals, who are able to provide guidance during the development and focusing correctly the application, as well as providing real test conditions and appropriate environments for the target audience.

The results does not allow to conclude if there is great interest on using the Microsoft Kinect, or any new interface device, by the general population. Even challenging in some cases, the user feel comfortable with gesture recognizing and considers easy to learn and to use this type of interface. Data generated in this analysis will be used as feedback for the development team to incorporate enhancements to the application.

Future work include applying usability tests on the elderly; realizing visuo-spatial memory tests in the laboratory of Neurosciences of the University; verify that using the application for training can really improve the memory storage capacity of the elderly; allow a free download of a version of the game.

\section{Acknowledgments}

The authors would thank the Araucaria Foundation for Financial Support.

\section{References}

[1] AGELIGHT, L.L.C.: Interface Design Guidelines for Users of All Ages. September, 2011. [Online]. Available: <www.agelight.com/webdocs/designguide.pdf>

[2] AL-RAZGAN, M. et al: Touchbased mobile phone interface guidelines and design recommendations for elderly people: A survey of the literature, in NEURAL INFORMATION PROCESSING, ser. Lecture Notes in Computer Science, T. Huang, Z. Zeng, C. Li, and C. Leung, Eds. Springer Berlin Heidelberg, 2012, vol. 7666, pp. 568-574. [Online]. Available: <http://dx.doi.org/10.1007/978-3-642-34478-7 69>

[3] ARCH, A. Web Accessibility for Older Users: A Literature Review, Internet, W3C, Tech. Rep., 2010. [Online]. Available: <http://www.w3.org/TR/2008/WD-wai-age-literature-20080514/>

[4] BÄCKMAN, L. Varieties of memory compensation by older adults in episodic remembering. In: POON, L. W., RUBIN, D. C.; WILSON, B. A. (Eds.). Everyday cognition in adulthood and late life. New York: Cambridge University Press, 1989. p. 509-544.

[5] BALTES, P. B.; BALTES, M. M. Psychological perspectives on successful aging: the model of selective optimization with compensation. New York: Cambridge University Press, 1990. Disponível em: $<$ http://dx.doi.org/10.1017/CBO9780511665684.003>. Acesso em: 20 ago. 2013.

[6] BASAK, C. et al. Can training in a real-time strategy video game attenuate cognitive decline in older adults? Psychology and aging, v. 23, n. 4, p. 765-777, dec. 2008. Disponível em: $<$ http://dx.doi.org/10.1037/a0013494>. Acesso em: 20 ago. 2013.

[7] BATENI, H. Changes in balance in older adults based on use of physical therapy vs the wii t gaming system: a preliminary study. Physiotherapy, v. 98, n. 3, p. 211-216, 2012. Disponível em: $<$ http://www.sciencedirect.com/science/article/pii/\%20S0031940611000472>. Acesso em: 20 ago. 2013.

[8] BISWAS, K.; BASU, S. Gesture recognition using Microsoft Kinect. In: AUTOMATION, ROBOTICS AND APPLICATIONS (ICARA), 5th International Conference on, 2011, Wellington, New Zealand. Proceedings... Wellington: IEEE Press, dec. 2011, p. 100-103.

[9] BOOT, W. R. et al. The effects of video game playing on attention, memory, and executive control. Acta Psychologica, v. 129, n. 3, p. 387-398, 2008. Disponível em: $<$ https://www.psych.uiuc.edu/reprints/index.php?site_id=1>. Acesso em: 20 ago. 2013. 
[10] BOUWHUIS, D. G. Design for person-environment interaction in older age: a gerontechnological perspective, Gerontechnology, vol. 2, pp.232-246, 2003.

[11] DUNLOSKY, J.; HERTZOG, C. Training programs to improve learning in later adulthood: helping older adults educate themselves. In: HACKER, D. J.; DUNLOSKY, J., GRAESSER, A. C. (Eds.). The educational psychology series. Mahwah, NJ, US: Lawrence Erlbaum Associates Publishers, 1998. p. 249-275.

[12] GERLING, K. et al. Game design for older adults: Effects of age-related changes on structural elements of digital games. In: HERRLICH, M.; MALAKA, R.; MASUCH, M. (Eds.). Entertainment Computing - ICEC 2012, Lecture Notes in Computer Science Springer Berlin Heidelberg, 2012. v. 7522. p. 235-242. Disponível em: <http://dx.doi.org/10.1007/978-3-642-33542-6_20>. Acesso em: 20 ago. 2013.

[13] GERLING, K. et al : Game design for older adults: Effects of age-related changes on structural elements of digital games, in ENTERTAINMENT COMPUTING - ICEC 2012, ser. Lecture Notes in Computer Science, M. Herrlich, R. Malaka, and M. Masuch, Eds. Springer Berlin Heidelberg, 2012, vol. 7522, pp. 235-242. [Online]. Available: <http://dx.doi.org/10.1007/978-3-642-33542-6 20>.

[14] GERLING, K. M.; SCHILD, J.; MASUCH, M. Exergame design for elderly users: the case study of silverbalance. In: INTERNATIONAL CONFERENCE ON ADVANCES IN COMPUTER ENTERTAINMENT TECHNOLOGY, $7^{\text {th }}$, ACE '10, 2010, New York, USA. Proceedings... New York: ACM, 2010, p. 66-69, 2010. Disponível em: <http://doi.acm.org/10.1145/1971630.1971650>. Acesso em: 20 ago. 2013.

[15] GERLING, K.; LIVINGSTON, I.; NACKE, L. For older adults: effects of age-related changes on structural elements of digital games. R. M. D.: Full-body motion-based game interaction for older adults. In: INTERNATIONAL CONFERENCE ON HUMAN FACTORS IN COMPUTING SYSTEMS, $30^{\text {th }}$, CHI' 12 , Austin, Texas, USA. Proceedings... Austin: ACM, 2012, p. 1873-1882.

[16] GERLING, K.; SMEDDINCK, J. Involving users and experts in motion-based game design for older adults. In: INTERNATIONAL CONFERENCE ON HUMAN FACTORS IN COMPUTING SYSTEMS, $31^{\text {th }}$, CHI'13,Paris, France. Proceedings... Paris: ACM, 2013.

[17] HARTIKAINEN, M., PEKKA SALONEN, E., TURUNEN, M.: Subjective evaluation of spoken dialogue systems using servqual. In: PROCEEDINGS OF THE EIGHTH INTERNATIONAL CONFERENCE ON SPOKEN LANGUAGE PROCESSING (INTERSPEECH 2004-ICSLP), Jeju Island, Korea (2004)

[18] IBGE. Perfil dos idosos responsáveis pelos domicílios no Brasil, 2000. Disponível em $<$ http://www.ibge.gov.br/home/estatistica/populacao/perfilidoso/perfidosos2000.pdf >. Acesso em 20 de Agosto de 2013

[19] IJSSELSTEIJN, W. et al : Digital game design for elderly users, in PROCEEDINGS OF THE 2007 CONFERENCE ON FUTURE PLAY, ser. Future Play '07. New York, NY, USA: ACM, 2007, pp. 17-22. [Online]. Available: <http://doi.acm.org/10.1145/1328202.1328206>

[20] IRIGARAY, T. Q.; SCHNEIDER, R. H.; GOMES, I. Efeitos de um treino cognitivo na qualidade de vida e no bem-estar psicológico de idosos. Psicologia: Reflexão e Crítica, v. 24, p. 810-818, 2011. Disponível em: $<$ http://www.scielo.br/scielo.php?script=sci_arttext\&pid=S0102-79722011000400022\&nrm=iso $>$. Acesso em: 20 ago. 2013.

[21] ISO, W. 1998. 9241-11. Ergonomic requirements for office work with visual display terminals (VDTs). Guidance on usability.

[22] JUNG, Y. et al. Games for a better life: effects of playing wii games on the well-being of seniors in a longterm care facility. In: AUSTRALASIAN CONFERENCE ON INTERACTIVE ENTERTAINMENT, 2009, New York, USA. Proceedings... New York: ACM, 2009, p. 5:1-5:6. Disponível em: $<$ http://doi.acm.org/10.1145/1746050.1746055>. Acesso em: 20 ago. 2013. 
[23] KONDORI, F. et al. 3d head pose estimation using the Kinect. In: WIRELESS COMMUNICATIONS AND SIGNAL PROCESSING,WCSP, 2011, Nanjing, China. Proceedings... Nanjing: IEEE, 2011, p. 1-4.

[24] LANGE, B. et al. Development and evaluation of low cost game-based balance rehabilitation tool using the microsoft kinect sensor. In: ENGINEERING IN MEDICINE AND BIOLOGY SOCIETY, EMBC, 2011, Boston, USA. Proceedings... Boston: IEEE, 2011, p. 1831-1834.

[25] LIKERT, R.: A technique for the measurement of attitudes. Archives of Psychology, 22(140), $1\{55$ (1932)

[26] LIVINGSTON, M. el al. Performance measurements for the Microsoft Kinect skeleton. In: VIRTUAL REALITY WORKSHOPS, VR, 2012, Costa Mesa, USA. Proceedings... Costa Mesa: IEEE, 2012, p. 119 120.

[27] LONGONI, A. Memória (A). São Paulo: Loyola, 2003. Disponível em: $<$ http://books.google.com.br/books?id=6aadhRihfugC>. Acesso em: 20 ago. 2013.

[28] MARIN, J. G.; NAVARRO, K. F. Serious games to improve the physical health of the elderly: a categorization scheme. In: INTERNATIONAL CONFERENCE ON ADVANCES IN HUMAN-ORIENTED AND PERSONALIZED MECHANISMS, TECHNOLOGIES, AND SERVICES, $4^{\text {th }}$, CENTRIC, Barcelona, Spain. Proceedings: Barcelona: IARIA, 2011, p. 64-71.

[29] MARTIN, C. et al. A real-time ergonomic monitoring system using the Microsoft Kinect. In: SYSTEMS AND INFORMATION DESIGN SYMPOSIUM (SIEDS), 2012 IEEE. p. 50-55, apr. 2012.

[30] MARTINS, V.F. et al: Usability evaluation of television based gestures and voice control. In: PROCEEDINGS OF LATINDISPLAY 2012/IDRC 2012 (2012)

[31] Microsoft: Microsoft Kinect SDK Documentation (April 2013). Disponível em: $<$ http://www.microsoft.com/en-us/kinectforwindows/develop/resources.aspx>. Acesso em: 20 ago. 2013.

[32] MILLER, G. A. The magical number seven, plus or minus two: some limits on our capacity for processing information. The Psychological Review, v. 63, n. 2, p. 81-97, mar. 1956. Disponível em: $<$ http://www.musanim.com/miller1956/>. Acesso em: 20 ago. 2013.

[33] MITCHELL, P.P.: A Step-by-Step Guide to Usability Testing. iUniverse, Inc., 0 edn. (2007)

[34] NIELSEN NORMAN GROUP. Senior Citizens (Ages 65 and older) on the Web. 2. ed. (online). Available: $<$ http://www.nngroup.com/reports/senior-citizens-on-the-web/>.

[35] NIELSEN, J.: Ten usability heuristics. Website (2005). Available: $<$ http://www.useit.com/papers/heuristic/heuristiclist.html $>$.

[36] NIELSEN, J.: Usability inspection methods. In: CONFERENCE COMPANION ON HUMAN FACTORS IN COMPUTING SYSTEMS. pp. 413-414. CHI '94, ACM, New York, NY, USA (1994), http://doi.acm.org/10.1145/259963.260531

[37] OBDRZALEK, S. et al. Accuracy and robustness of Kinect pose estimation in the context of coaching of elderly population. In: ENGINEERING IN MEDICINE AND BIOLOGY SOCIETY, EMBC, 2012, San Diego, USA. Proceedings... San Diego: IEEE, 2012, p. 1188-1193.

[38] OpenKinect: OpenKinect Documentation (April 2013). Available: $<$ http://openkinect.org/wiki/Documentation>.

[39] OpenNI organization: OpenNI User Guide (November 2010). Available: $<$ http://www.openni.org/documentation> 
[40] PARAJULI, M. et al. Senior health monitoring using Kinect. In: COMMUNICATIONS AND ELECTRONICS (ICCE), 2012 Fourth International Conference on. p. 309-312, aug. 2012.

[41] PHIRIYAPOKANON, T.: Is a Big Button Interface Enough for Elderly Users?: Towards User Interface Guidelines for Elderly Users. LAP Lambert Acad. Publ., 2011. [Online]. Available: $<$ http://books.google.com.br/books?id=GF7RygAACAAJ $>$.

[42] REDISH, J. CHINELL, D. Designing Web Sites For Older Adults: A Review of Recent Literature Prepared For AARP. $\quad$ December, $2004 . \quad$ [Online]. Available: $<\mathrm{http} / /$ assets.aarp.org/www.aarp.org/articles/research/oww/aarp-litreview2004.pdf>.

[43] SHNEIDERMAN, B.; PLAISANT, C. Designing the user interface: strategies for effective humancomputer interaction. 4. ed. Massachusetts: Pearson Addison Wesley, 2004.

[44] SMEDDINCK, J. et al. Did they really like the game? - challenges in evaluating exergames with older adults. In: INTERNATIONAL CONFERENCE ON HUMAN FACTORS IN COMPUTING SYSTEMS, $30^{\text {th }}$, CHI'12, Austin, Texas, USA. Proceedings...Austin: ACM, 2012.

[45] SOUZA, J. N. D.; CHAVES, E. C. O efeito do exercício de estimulação da memória em idosos saudáveis. Revista da Escola de Enfermagem da USP, v. 39, p. 13-19, mar. 2005. Disponível em: $<$ http://www.scielo.br/scielo.php?script=sci_arttext\&pid=S0080-62342005000100002\&nrm=iso $>$. Acesso em: 20 ago. 2013.

[46] VERHAEGHEN, P. The interplay of growth and decline: Theoretical and empirical aspects of plasticity of intellectual and memory performance in normal old age. In: R. D. Hill, L. Bäckman, \& A. Stigsdotter Neely (Eds.), Cognitive rehabilitation in old age (pp. 3-22). New York: Oxford University Press. Inc, 2000. p. 3-22.

[47] Website Analysis and MeasureMent Inventory:Web Usability Questionnaire. Available: $<$ http://www.wammi.com>

[48] WEISMAN, S.: Computer games for the frail elderly, The Gerontologist, vol. 23, no. 4, pp. 361-363, 1983. [Online]. Available: <http://gerontologist.oxfordjournals.org/content/23/4/361.short>

[49] YASSUDA, M. S. et al. Treino de memória no idoso saudável: benefícios e mecanismos. Psicologia: Reflexão e Crítica, v. 19, p. 470-481, 2006. Disponível em: $<$ http://www.scielo.br/scielo.php?script=sci_arttext\&pid=S0102-79722006000300016\&nrm=iso $>$. Acesso em: 20 ago. 2013.

[50] ZAJICEK, M. Successful and Available Interface Design Exemplars for Older Users. Interacting With Computers, 16 (3), 411-430. 